\title{
Impaired Classical Eyeblink Conditioning in Cerebellar-Lesioned and Purkinje Cell Degeneration (pcd) Mutant Mice
}

\author{
Lu Chen, Shaowen Bao, Jon M. Lockard, Jeansok J. Kim, and Richard F. Thompson \\ Neuroscience Program, University of Southern California, Los Angeles, California 90089-2520
}

\begin{abstract}
Converging lines of evidence from rabbits, rats, and humans argue for the crucial involvement of the cerebellum in classical conditioning of the eyeblink/nictitating membrane response in mammals. For example, selective lesions (permanent or reversible) of the cerebellum block both acquisition and retention of eyeblink conditioning. Correspondingly, electrophysiological and brain-imaging studies indicate learning-related plasticity in the cerebellum. The involvement of the cerebellum in eyeblink conditioning is also supported by stimulation studies showing that direct stimulation of the two major afferents to the cerebellum (the mossy fibers emanating from the pontine nucleus and climbing fibers originating from the inferior olive) can substitute for the peripheral conditioned stimulus (CS) and unconditioned stimulus (US), respectively, to yield normal behavioral learning. In the present study, we examined the relative contribution of the cerebellar cortex versus deep nuclei (specifically
\end{abstract}

the interpositus nucleus) in eyeblink learning by using mutant mice deficient of Purkinje cells, the exclusive output neurons of the cerebellar cortex. We report that Purkinje cell degeneration $(p c d)$ mice exhibit a profound impairment in the acquisition of delay eyeblink conditioning in comparison with their wild-type littermates. Nevertheless, the pcd animals did acquire a subnormal level of conditioned eyeblink responses. In contrast, wild-type mice with lesions of the interpositus nucleus were completely unable to learn the conditioned eyeblink response. These results suggest that both cerebellar cortex and deep nuclei are important for normal eyeblink conditioning.

Key words: Purkinje cells; mutant mice; eyeblink conditioning; learning; memory; cerebellum; interpositus nucleus; longterm depression
Although the importance of the cerebellum in classical eyeblink conditioning has been well documented during the past 15 years (McCormick et al., 1981, 1982; Lincoln et al., 1982; Clark ct al., 1984; McCormick and Thompson, 1984a,b; Lavond et al., 1985; Yeo et al., 1985; Berthier and Moore, 1986, 1990; Mauk et al., 1986; Steinmetz et al., 1986, 1989; Schreurs et al., 1991; Clark et al., 1993; Krupa et al., 1993; Nordholm et al., 1993; Molchan et al., 1994), because of the difficulty in lesioning all cerebellar cortex without damage to the interpositus nucleus, the relative importance of these two structures is unclear. Both the cortex and the deep nuclei receive mossy fiber and climbing fiber projections (Chan-Palay, 1977; Courville et al., 1977; Kitai et al., 1977; Voogd, 1982; Ito, 1984; Shinoda et al., 1992; Steinmetz and Sengelaub, 1992; Mihailoff, 1994), pathways thought to convey information about peripheral conditioned stimulus (CS) and unconditioned stimulus (US), respectively (Thompson, 1986, 1990), and therefore both are potentially capable of supporting CS-US associations. Consistent with this view, long-term depression (LTD) and longterm potentiation (LTP), two forms of synaptic plasticity implicated in associative learning, have been demonstrated in the

Received Nov. 1, 1995; revised Jan. 19, 1996; accepted Jan. 23, 1996.

This work was supported by National Institutes of Health Grant 1F32MN10521-01 BNR to J.J.K.; National Institute of Mental Health Grant MH51197 to D.G.L.; and National Science Foundation Grant IBN9215069, National Institute on Aging Grant AF05142, and a grant from Sankyo Co., LTD to R.F.T. Lu Chen and Shaowen Bao made equal contributions to this study. We thank Chong Chen for suggestions, David G. Lavond and Larry W. Swanson for comments on this manuscript, and Robert E. Clark, Jeffrey S. Grethe, and David J. Krupa for technical assistance.

Correspondence should be addressed to Jeansok J. Kim, Neuroscience Program, University of Southern California, Los Angeles, CA 90089-2520.

Copyright $\odot 1996$ Society for Neuroscience $0270-6474 / 96 / 162829-10 \$ 05.00 / 0$ cerebellar cortex and the deep nuclei, respectively (Ito et al., 1982; Ekerot and Kano, 1985; Racine et al., 1986; Linden, 1994; Chen and Thompson, 1995). Although some have reported that the cortex is necessary (Yco et al., 1984, 1985), others have suggested that although the cortex is involved, it is not necessary for eyeblink conditioning (Lavond et al., 1987; Lavond and Steinmetz, 1989).

Recently, various mutant (e.g., spontaneous mutants, gene knockouts, and transgenics) mice have been used to study the neural mechanisms underlying learning and memory (for reviews, see Goldowitz and Eisenman, 1992; Grant and Silva, 1994). In essence, these animals provide an effective means to determine the importance of, for example, a particular type of neuron or a specific protein in learned behavior. Eyeblink conditioning is an ideal behavioral model for testing various mutants because the neural circuitry involved in this learning has been well characterized (Thompson, 1986, 1990).

In the present study, we first determined whether associative eyeblink conditioning is feasible (see also Aiba et al., 1994) and whether the cerebellum is crucial for this type of learning in wild-type mice. We then employed Purkinje cell degeneration (pcd) mutant mice to dissect the components of cerebellar circuitry involved in eyeblink conditioning. The $p c d$ mutants are born with Purkinje cells, but during the course of development they are all lost by the third and fourth postnatal weeks (Mullen et al., 1976; Landis and Mullen, 1978; Goodlett et al., 1992). Because Purkinje cells are the sole output neurons of the cerebellar cortex (Ito, 1984), the pcd mice are completely devoid of neural outputs from the cerebellar cortex. A phaseolus vulgaris leucoagglutinin (PHA-L) tract tracing study in- 
cluded here showed that there were no aberrant projections from the cortex to the deep nuclei in pcd mutants. Thus, the $p c d$ mice provide fully reproducible, natural lesions of the entire cerebellar cortex.

\section{EXPERIMENT 1. EYEBLINK CONDITIONING AND CEREBELLAR LESIONS IN MICE}

\section{Materials and Methods}

\section{Subjects and surgeries}

Adult male C57BL/6J mice (Jackson Laboratories, Bar Harbor, ME), weighing between 22 and $27 \mathrm{gm}$, were housed individually in a colony room with a $12 \mathrm{hr}$ light/dark cycle. Subjects had ad libitum access to food and water except during the hehavinal experiment. All experiments were conducted during the light phase of the cycle. Before the experiment, animals were assigned randomly to either paired, pseudo-random, or lesioned groups.

While they were under ketamine $(80 \mathrm{mg} / \mathrm{kg}$, i.p.) and xylazine $(20$ $\mathrm{mg} / \mathrm{kg}$, i.p.) anesthesia, animals were implanted subcutaneously with four wires (Tellon-coated stainless steel, 0.003 inch bare, 0.0045 inch coated; A-M Systems, Everett, WA) to the left upper eyelid. The tips of the wires were exposed, and two of the wires were used to record differential electromyograph (EMG) from obicularis oculi, and the remaining two wires were used to deliver periorbital shock. A four-pin strip connector to which the wires were soldered was cemented to the skull of the animal with dental acrylic. Animals in the lesioned group reccived bilateral electrolytic lesions of the interpositus nucleus (coordinates from the hregma: $6.5 \mathrm{~mm}$ posterior, $1.7 \mathrm{~mm}$ lateral, and $3.5 \mathrm{~mm}$ ventral) by passing anodal current $(1.5 \mathrm{~mA}$ for $10 \mathrm{sec})$ through an electrode (insulated with epoxy, except for $0.5 \mathrm{~mm}$ at the tip) just before the eyelid surgery.

\section{Behavioral training}

For eyeblink conditioning, we used the techniques developed by Skelton (1988) on rats and adapted by Aiba et al. (1994) in mice. Training took place in a small cylindrical Plexiglas container (3.75 inch diameter) that was placed inside a sound- and light-attenuating chamber (Ralph Gerbrands Company, Arlington, MA). The strip connector was attached to the mating plug of a commutator that has channels to relay EMG signals and to deliver the shock. After $1 \mathrm{~d}$ of habituation, animals underwent either paired or pseudo-random training. The daily paired training consisted of 100 trials grouped in 10 blocks. Each block included one CS alone (the first trial), onc US alone (the sixth trial), and cight CS-US paired trials. The CS and US were a $352 \mathrm{msec}$ tone $(1000 \mathrm{~Hz}, 80 \mathrm{~dB}, 5$ $\mathrm{msec}$ rise/fall time) and a coterminating $100 \mathrm{msec}$ shock $(100 \mathrm{~Hz}$ biphasic square pulses), respectively, with a $252 \mathrm{msec}$ interstimulus interval and a randomized intertrial interval between 20 and $40 \mathrm{sec}($ mean $=30 \mathrm{sec}$ ). The US intensity used was the minimal voltage required to elicit an eyeblink/head turn response, and the US intensity was adjusted daily for each animal. Animals assigned to the paired group received $5 \mathrm{~d}$ of paired training followed by $4 \mathrm{~d}$ of CS-alone extinction trials. In pseudo-random training, animals received the same number of CS and US as in the paired condition, but they occurred at random intervals and were never paired. The pseudo-random group received $5 \mathrm{~d}$ of unpaired CS-US training followed by $5 \mathrm{~d}$ of CS-US paired training. Animals with cerebellar lesions underwent $10 \mathrm{~d}$ of CS-US paired training.

\section{EMG analysis}

For conditioned response (CR) analysis, the EMG signal was amplified in the band of $300-5000 \mathrm{~Hz}$ and sent to a window discriminator where the number of pulses above the noise envelop was sampled and stored by a computer into 189 consecutive $4 \mathrm{msec}$ bins. The discriminated EMG activity was analyzed trial by trial using the following criteria. (1) The trial was considered invalid and excluded from analysis if during the $252 \mathrm{msec}$ pre-CS period the average unit count per bin was higher than two (indicating high EMG activity before the CS onset), or the SD of unit counts per bin was larger than the average unit count per bin (indicating unstable EMG activity before the CS onsct), or the avcragc unit count within $28 \mathrm{msec}$ (seven bins) after the CS onset was bigger than the average plus the SD of the pre-CS period (indicating short-latency startle response to the CS). (2) The CR was defined as the average unit count of any consecutive seven bins during the period from $84 \mathrm{msec}$ after tone onset to the onset of the shock (total $=168 \mathrm{msec}$ ) that was higher than average plus SD plus one unit per bin of pre-CS period. [For the $C R$ measurement, a constant value of one unit per bin was included as a CR
A

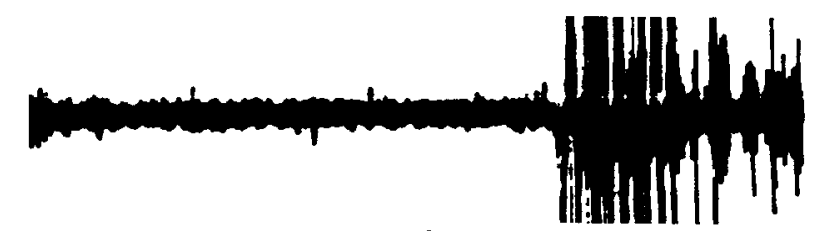

B

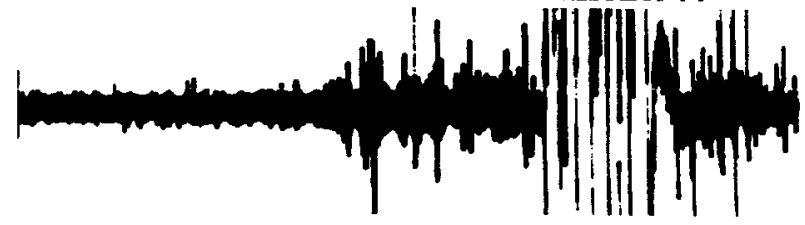

C

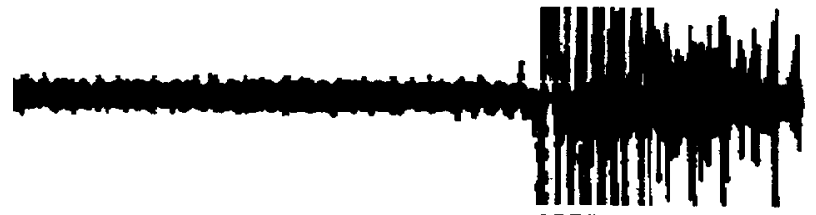

$\mathrm{D}$

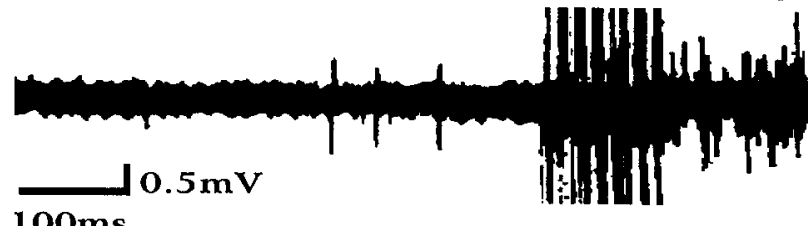

$100 \mathrm{~ms}$

CS

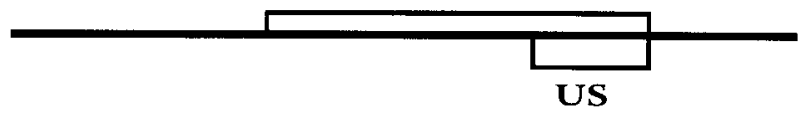

Figure 1. Typical EMG responscs observed from a normal mouse on $(A)$ day 1 and $(B)$ day 5 and from a cerebellar-lesioned mouse on $(C)$ day 1 and $(D)$ day 10 of eyeblink conditioning.

threshold. This value is comparable to the CR threshold value $(0.5 \mathrm{~mm}$ deflection in the eyelid/nictitating membrane response) used in the rabbit eyeblink conditioning paradigm.] For tone-alone trials, the period for scoring a CR was extended to the termination of the tone (total $=268$ msec).

The UR amplitudes were determined from US-alone trials. Because the shock US saturates the EMG activity and because the shock offset is not instantaneous (because of capacitance), we analyzed the unit activity during the $100 \mathrm{msec}(25 \mathrm{bins}$ ) period $50 \mathrm{msec}$ after the termination of the US. The UR amplitude was defined as the difference in averaged unit activity during the UR period and averaged unit activity $100 \mathrm{msec}$ before the US onset.

\section{Histology}

When the behavioral studies were completed, the animals were given an overdose of sodium pentobarbital and perfused with $0.9 \%$ saline followed by $10 \%$ buffered formalin. The brains were sectioned on a microtome ( 80 $\mu \mathrm{m}$ sections), mounted on gelatin-coated slides, and stained with Prussian blue and cresyl violet. The slides were scanned into a computer using a 35 $\mathrm{mm}$ Nikon film scanner (LS-3510 AF) for lesion verification.

\section{Results}

Figure 1 represents the typical EMG activity patterns observed from a normal wild-type mouse in response to paired tone-airpuff presentations before $(A)$ and after $(B)$ conditioning. Before the animal acquired eyeblink CRs (day 1 ), there were no differences in EMG activity between pre-CS and CS periods. The saturated EMG signal during the US period is the shock artifact. After termination of the shock, there was an increase in EMG activity (most likely an unconditioned EMG response to the shock). After the animal learned (day 5), there was a substantial increase in EMG activity during the CS period, reflecting a conditioned EMG response from the eye. In the cerebellar-lesioned animal, the EMG activity during the CS period did not increase from day 1 


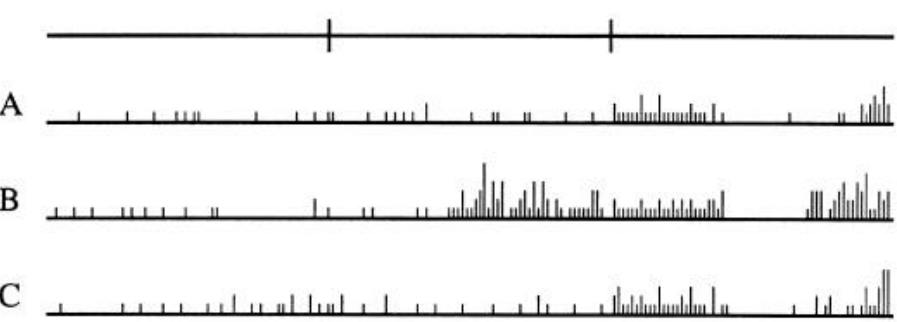

$\mathrm{D}$

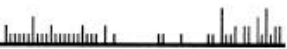

Figure 2. Examples of discriminated EMG activity from a normal mouse on $(A)$ day 1 and $(B)$ day 5 and from a cerebellar-lesioned mouse on $(C)$ day 1 and $(D)$ day 10 of eyeblink conditioning. The first and second vertical lines denote the onset of CS and US, respectively.

$(C)$ to day $10(D)$ of paired training. Examples of discriminated EMG units can be seen in Figure 2. Although the normal mouse displayed an increase in discriminated units during the CS period from day $1(A)$ to day $5(B)$ of training, the cerebellar-lesioned mouse showed no increase in discriminated units from day $1(C)$ to day $10(D)$ of training.

Figure 3 shows a transverse brain section from a typical mouse in the cerebellar-lesioned group. Cerebellar-lesioned animals sustained substantial bilateral destruction of the interpositus nucleus and the overlying cerebellar cortex.

Figure 4 presents the percentage $(A)$ and the amplitude $(B)$ of eyeblink CRs displayed by paired $(n=6)$, pseudo-random $(n=$ $6)$, and lesioned $(n=6)$ groups. The percentage of CRs of the paired group increased gradually and significantly during the $5 \mathrm{~d}$ of training [linear trend analysis for all time points, $F_{(1,24)}=22.76$, $p<0.01$ ], reaching an asymptote of $66 \%$. When switched to extinction trials, the previously acquired CRs decreased progressively to $7 \%$ over $4 \mathrm{~d}$ [linear trend analysis, $F_{(1,18)}=21.96, p<$ $0.01]$. The animals in the pseudo-random group exhibited no reliable increase in CRs over the course of $5 \mathrm{~d}$ of unpaired CS-US presentations [linear trend analysis, $F_{(1,24)}=6.28, p>0.05$ ]. When switched to paired trials, however, they acquired CRs in a manner similar to that of the paired group [linear trend analysis, $\left.F_{(1,24)}=28.81, p<0.01\right]$ (maximum of $71 \%$ ). In contrast to the unlesioned paired group, the cerebellar-lesioned animals failed to show a reliable increase in CRs even with $10 \mathrm{~d}$ of paired training [linear trend analysis, $F_{(1,423)}=3.71, p>0.05$ ]. In all three groups, trends similar to those of percentage of CRs were observed in CR amplitudes.

\section{EXPERIMENT 2: EYEBLINK CONDITIONING IN PCD MICE}

\section{Materials and Methods}

Subjects, surgeries, behavioral training, and histology

Adult male $p c d(n=11)$ and wild-type littermate mice $(n=10)$ of C57BL/6J strain (Jackson Laboratories), weighing between 20 and 30 $\mathrm{gm}$, were housed and prepared for eyeblink conditioning in a manner similar to that described in Experiment 1. Because pcd is a recessive autosomal mutation (Mullen et al., 1976), the actual genotypes of the wild-type mice may include both homozygotes ( $w t / w t)$ and heterozygotes ( $w t / p c d)$. Both $p c d$ and wild-type animals received $10 \mathrm{~d}$ of CS-US paired training followed by $4 \mathrm{~d}$ of CS-alone extinction training. Animals were trained "blind" by the experimenters (L.C. and S.B.), and the EMG analysis was carried out as described previously. In addition, we analyzed CR onset and CR peak latencies in the following manner. (1) The CR onset latency was computed as the first time, during the period between the CS onset and the US onset, at which the average unit count of any consecutive seven bins $(28 \mathrm{msec})$ was higher than the average plus SD plus one of pre-CS period. (2) The CR peak latency was calculated as the time between the CS and the US onsets at which the average unit count of any consecutive seven bins was the highest. On tone-alone trials, the period for scoring CR onset and peak latencies, extended to the tone offset. After termination of the experiment, the animals were given an overdose of sodium pentobarbital and perfused with $0.9 \%$ saline followed by $10 \%$ buffered formalin. The brains were then removed, and transverse sections were made throughout the cerebellum ( $20 \mu \mathrm{m}$ using a cryostat) and stained with cresyl violet to verify the phenotype of all animals. Transverse sections were also made at the level of the hippocampus, the basal pontine gray, and the inferior olive.

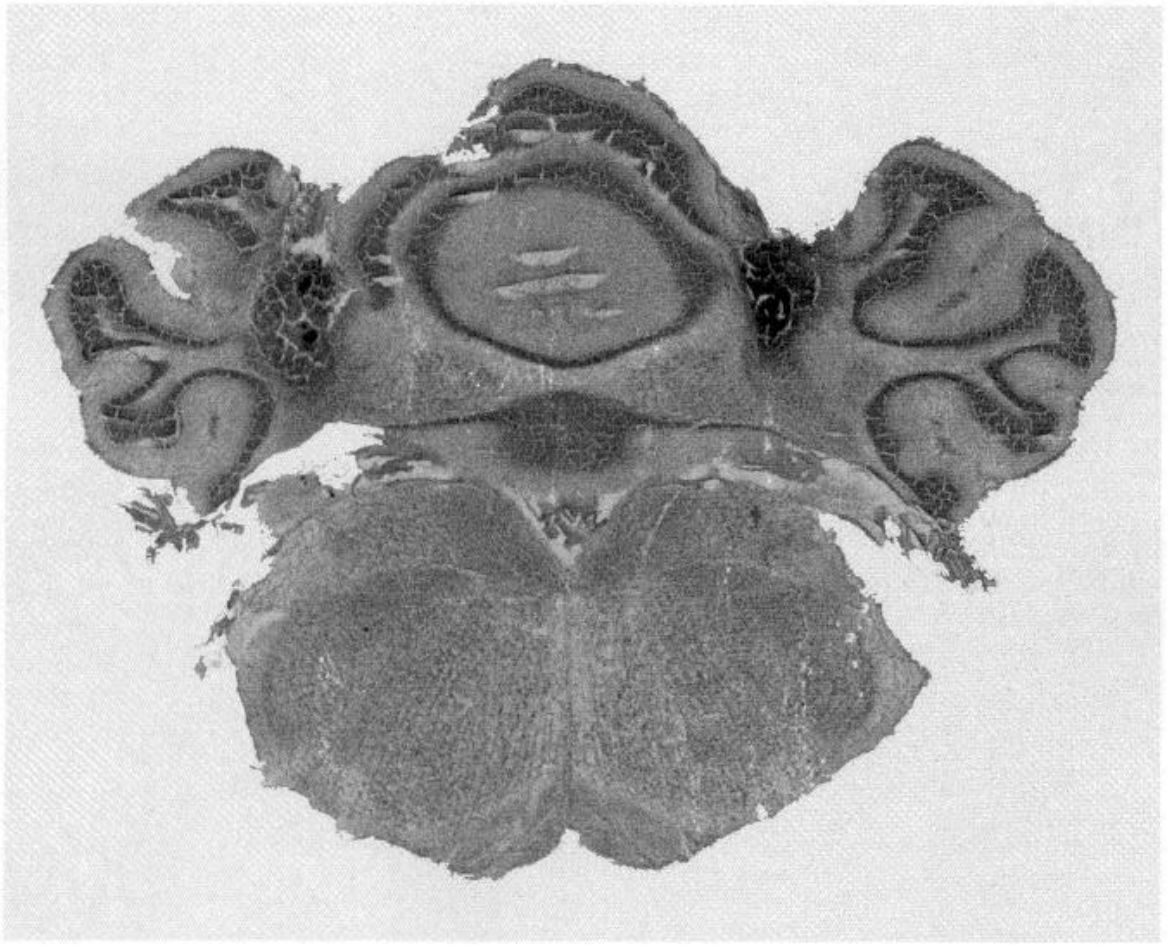

Figure 3. A transverse brain section stained with Prussian blue and cresyl violet from a typical animal with bilateral electrolytic cerebellar lesions. 

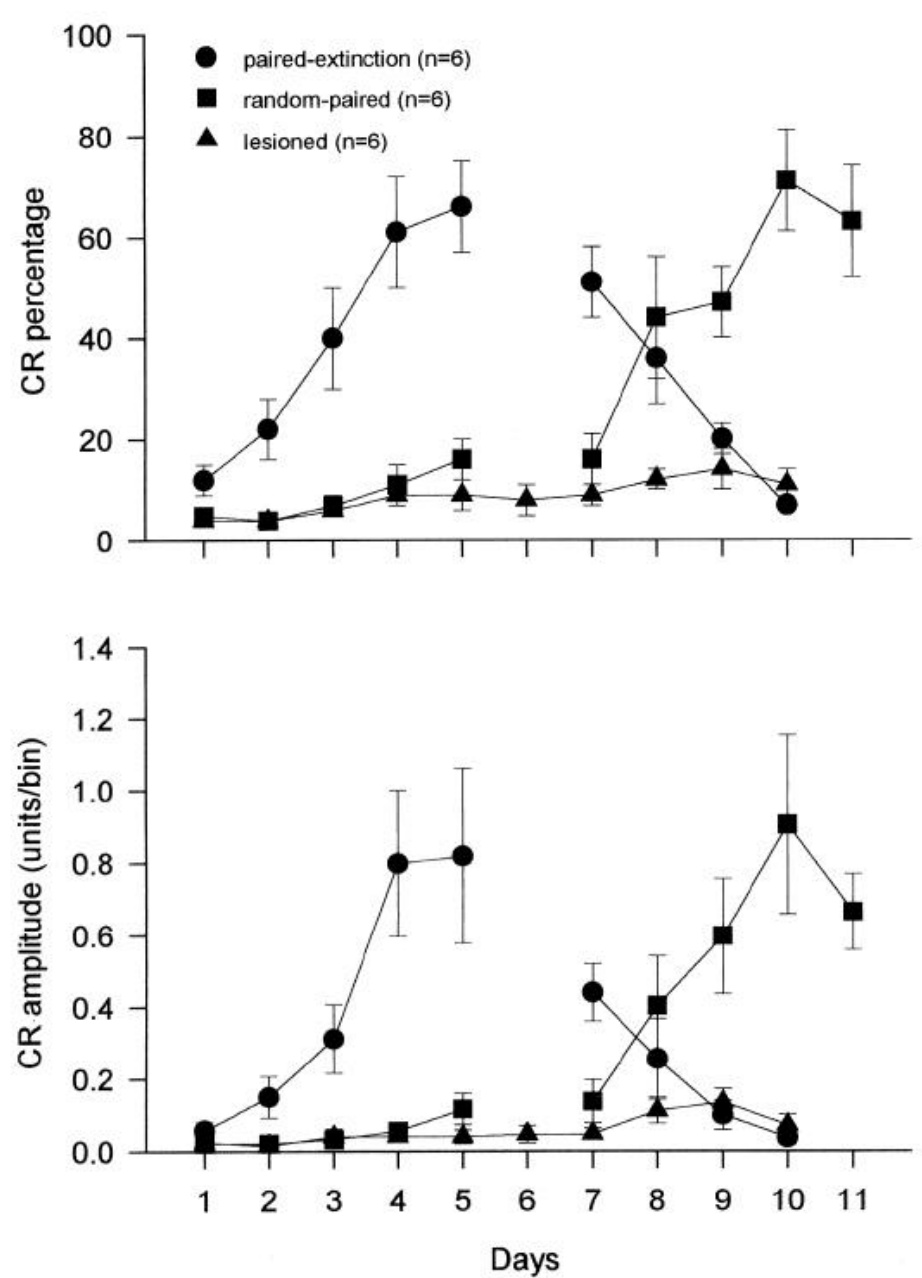

Figure 4. Percentage of CRs (top) and CR amplitudes (bottom) from paired $(\bullet)$, pseudo-random $(\boldsymbol{\square})$, and cerebellar-lesioned $(\boldsymbol{\Lambda})$ groups during acquisition and extinction training.

\section{PHA-L tract tracing}

The anterograde tracer PHA-L was used to show that there were no aberrant projections from the cerebellar cortex to the deep nuclei in the $p c d$ mutants. Three pcd and two wild-type mice (age-matched to those used in eyeblink conditioning) were used. Under ketamine-xylazine anesthesia, a glass micropipette (tip diameter ranging between 10 and 15 $\mu \mathrm{m})$ was stereotaxically positioned in the molecular, Purkinje cell, and granular layers of the cerebellum (lobulus simplex). Injections of a $2.5 \%$ solution of PHA-L (Vector Labs) in $0.1 \mathrm{~m}$ sodium PBS, $\mathrm{pH} 7.4$, were made during a 10 min period by applying a $+5 \mu \mathrm{A}$ current from a constant current source (Stoelting, Wood Dale, IL), pulsed at $7 \mathrm{sec}$ intervals. A survival time of $10-16 \mathrm{~d}$ was given for optimal transport of the tracer.

Fixation was performed by deeply anesthetizing the animal with sodium pentobarbital $(65 \mathrm{mg} / \mathrm{kg}$, i.p.) and perfusing with $200 \mathrm{ml}$ of ice-cold $4.0 \%$ paraformaldehyde in $0.1 \mathrm{M}$ sodium borate buffer, $\mathrm{pH} 9.5$, after a brief saline rinse to remove the blood. The brains were then removed and postfixed overnight at $4^{\circ} \mathrm{C}$ in the same fixative containing $10 \%$ sucrose.

After the brain was frozen, serial $30 \mu \mathrm{m}$ thick sections were cut on a sliding microtome. All sections were saved in a one-in-four series. One series was then processed for immunohistochemistry with an anti-PHA-L serum raised in rabbits (Dako Labs, Carpinteria, CA), at a dilution of 1:1000. The primary antiserum was localized using a variation of the avidin-biotin-complex system described in detail by Gerfen and Sawchenko (1984). In brief, the sections were incubated for $1 \mathrm{hr}$ at room temperature in a solution of biotinylated goat anti-rabbit IgG (Vector Labs), and then placed in the mixed avidin-biotin-horseradish peroxidase (HRP) complex solution for the same period of time. The Vectastain Elite $\mathrm{ABC}$ kit (Vector, Burlingame, $\mathrm{CA}$ ) was used, and the working solution of avidin-biotin-HRP complex was prepared by adding $90 \mu \mathrm{l}$ of

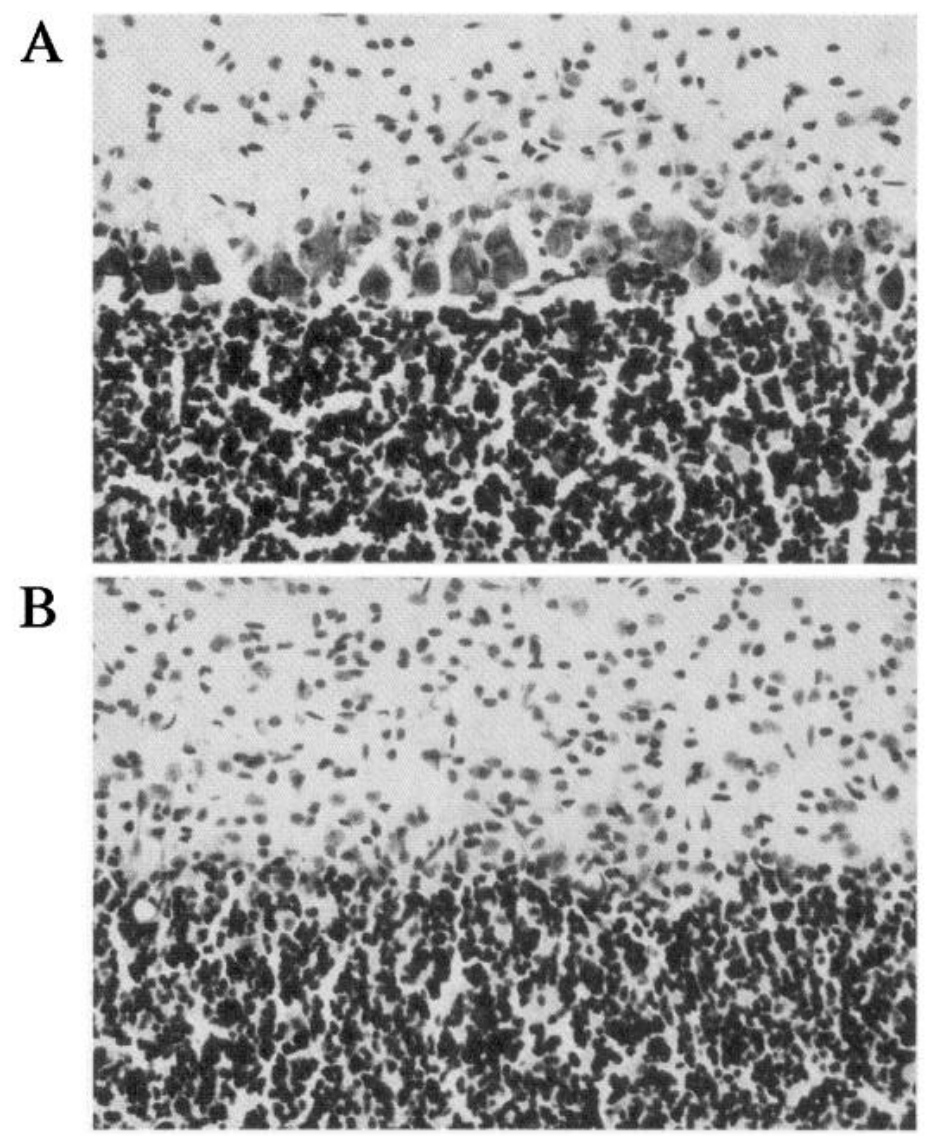

Figure 5. Transverse sections of the cerebellum stained with cresyl violet from $(A)$ wild-type and $(B) p c d$ mutant mice.

reagent $\mathrm{A}$ and $90 \mu \mathrm{l}$ of reagent $\mathrm{B}$ to $10 \mathrm{ml}$ of $0.02 \mathrm{M}$ potassium PBS, $\mathrm{pH}$ 7.4. The sections were recycled through the biotinylated antibody and the avidin-biotin-HRP complex and then processed for peroxidase histochemistry using a $0.05 \%$ solution of diaminobenzidine (Polyscience, Niles, IL). The sections were mounted on gelatin-coated slides, and the reaction product was intensified by placing the slides in a $0.005 \%$ aqueous solution of osmium tetroxide for $30 \mathrm{~min}$, in a $0.05 \%$ aqueous solution of theocarbohydrazide (EM Sciences, Ithaca, NY) for $15 \mathrm{~min}$, and in the osmium solution for an additional $30 \mathrm{~min}$. Slides were then dehydrated and coverslipped with DPX, and an adjacent series was stained with cresyl violet for reference purposes.

\section{Results}

Figure 5 shows a cerebellar section stained with cresyl violet from typical wild-type $(A)$ and $p c d(B)$ mice. As can be seen, the cerebellar section of the $p c d$ mouse is completely devoid of Purkinje cells. We examined all regions of the cerebellum (anterior and posterior lobes) from $p c d$ mice and found no Purkinje neurons. In contrast, a layer of Purkinje neurons is visible in the cerebellar section of the wild-type mouse. In addition to the Purkinje cells, there seems to be a slight disruption of the cerebellar granule cell layer in the $p c d$ mutants. Other structures that have been implicated in eyeblink conditioning, such as the hippocampus, the interpositus nucleus, the inferior olive, and the basal pontine gray were also examined (Fig. 6). Neurons in the inferior olive seem to be smaller in size, whereas the interpositus, basal pontine gray, and hippocampus seem to be qualitatively normal in the pcd mutants.

Figure 7 represents coronal sections of the cerebellum from $p c d$ $(A)$ and wild-type $(B)$ mice injected with PHA-L in the cerebellar cortex. The figures on the left depict adjacent sections stained with cresyl violet for reference purposes. As can be seen from the 


\section{wildtype}
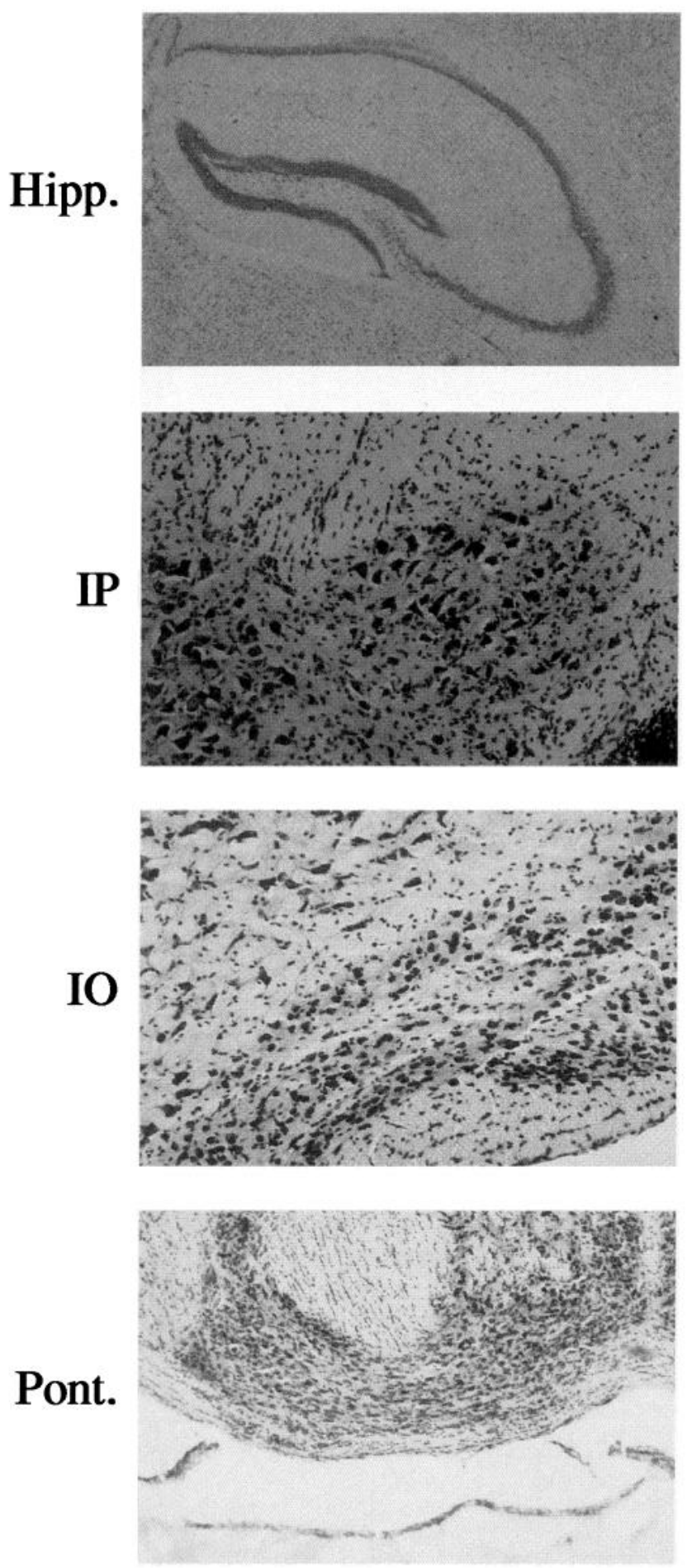

pcd
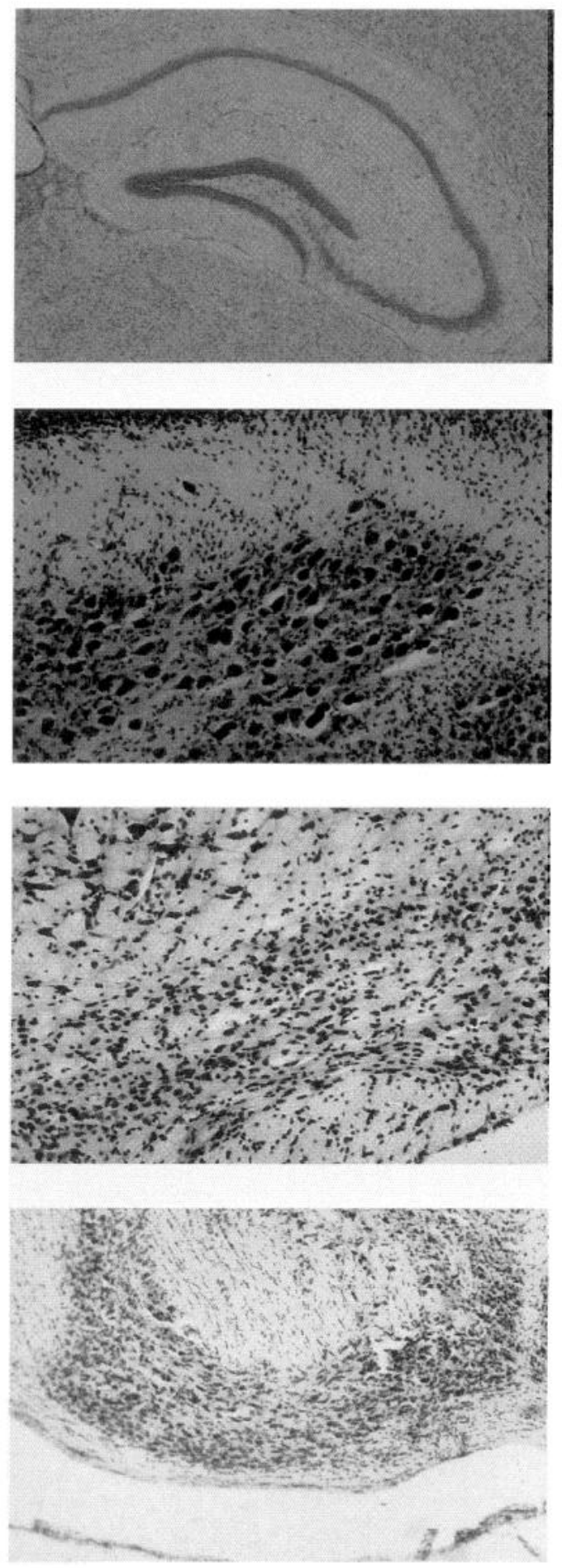

Figure 6. Transverse brain sections from wild-type and pcd mice. Hipp., Hippocampus; IP, interpositus nucleus; IO, inferior olive; Pont., basal pontine gray.

bright-field photomicrographs (figures on the right), the cerebellar section from the wild-type mouse shows intense PHA-Limmunoreactive labeling in the deep nuclei after an injection confined to the cerebellar cortex. In contrast, no PHA-Limmunoreactive fibers are present in the deep nuclei of the pcd mouse, even with a much larger injection in the cortex. Figure 8 shows higher magnification of the deep nuclei from $p c d(A)$ and wild-type $(B)$ animals. Once again, immunoreactive labeling is intense in the wild-type and completely absent in the $p c d$ animal.

Overall, the $p c d$ mice exhibited a significant impairment in the acquisition of conditioned eyelid EMG responses in comparison to the wild-type mice (Fig. 9) [one-way ANOVA on percentage of 
A
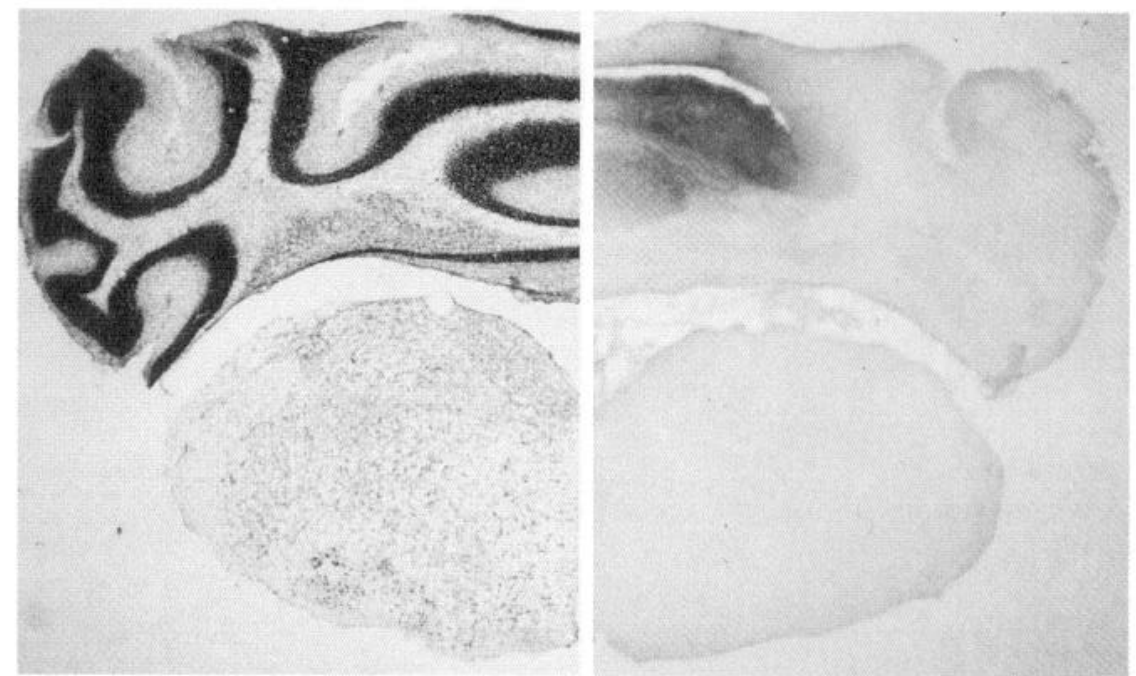

B

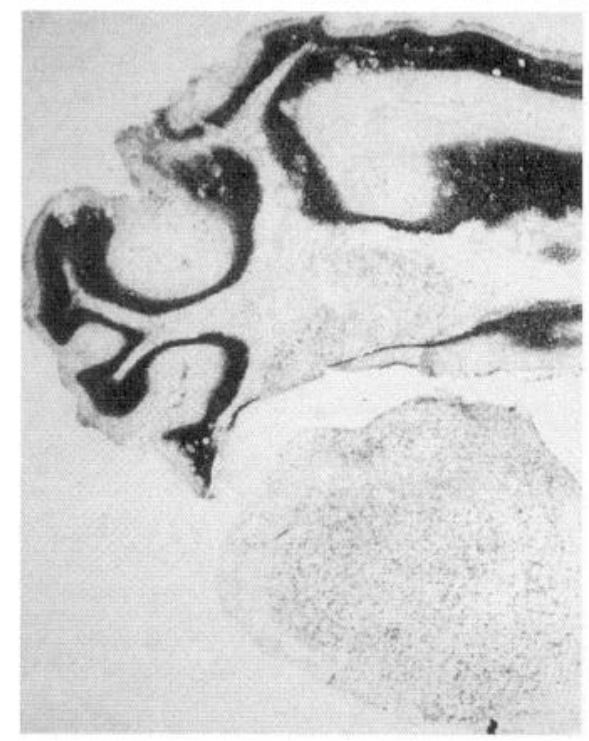

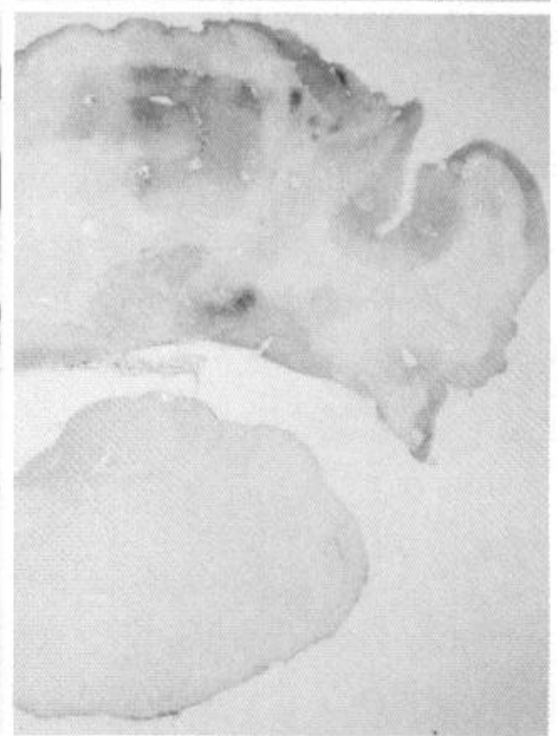

Figure 7. Transverse sections (magnified $20 \times)$ of the cerebellum from $(A) p c d$ and $(B)$ wild-type mice injected with PHA-L in the cerebellar cortex. a paired manner, as did Aiba et al. (1994) using a similar procedure. The CRs were not observed in the group in which the CS and US were randomly presented. Furthermore, the acquired CRs were extinguished with repeated CS-alone presentations. As shown previously in rabbits, rats, and humans (Thompson, 1986; Skelton, 1988; Daum et al., 1993; Lavond et al., 1993), lesions of the cerebellum (specifically the interpositus nucleus) also completely abolish eyeblink learning in mice. Thus, the cerebellum is critically involved in eyeblink conditioning in mice.

The results from the second study with $p c d$ mice that are devoid of Purkinje cells indicate that the cerebellar cortex plays an important role in eyeblink conditioning. The pcd mice, which completely lack cortical efferents to the deep nuclei (as shown by the PHA-L tract tracing), were strongly impaired in eyeblink learning; however, they still exhibited a low but significant level of eyeblink CRs during the course of training. A recent study indicated that the Purkinje cell number correlates highly with the rate of eyeblink learning in rabbits; i.e., animals with more Purkinje cells show stronger eyeblink conditioning than animals with fewer Purkinje cells (Woodruff-Pak et al., 1990). Interestingly, the CRs exhibited by the pcd animals tend to have shorter peak latencies than those CRs displayed by the wild types. The incomplete impairment in eyeblink conditioning and alterations in CR timing
In the first study we demonstrated that associative eyeblink con-

ditioning is feasible in mice when the CS and US are presented in mice (Fig. 11), and both groups exhibited extinction during the CS-alone trials (Fig. 9).

\section{DISCUSSION}



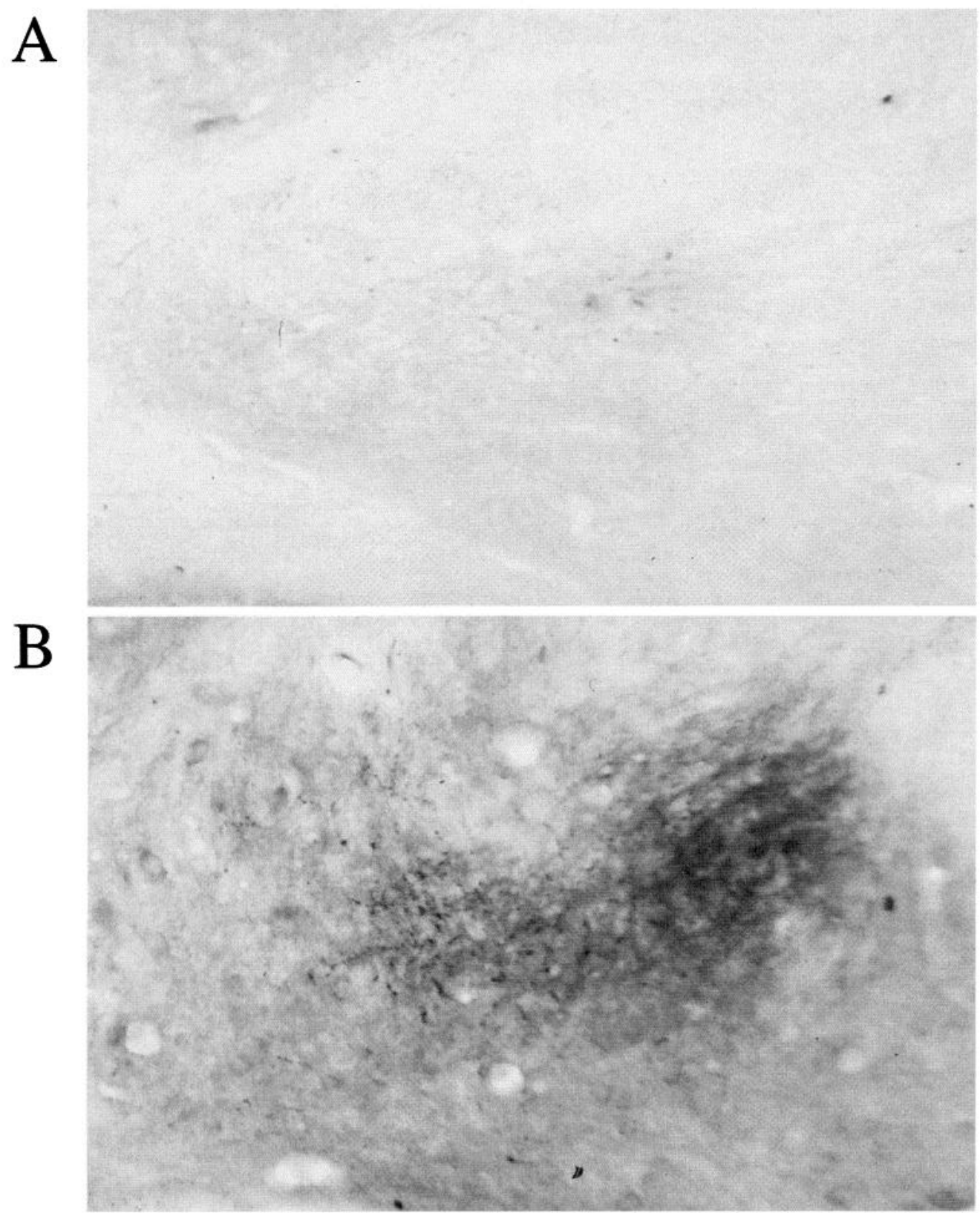

Figure 8. A higher magnification $(200 \times)$ of the deep nuclei from $(A) p c d$ and $(B)$ wild-type mice injected with PHA-L in the cerebellar cortex. have been reported previously in rabbits with confined and limited cerebellar cortical lesions (Lavond et al., 1987; Lavond and Steinmetz, 1989; Logan, 1991; Perrett et al., 1993). In contrast to the $p c d$ mice, the interpositus-lesioned mice in the first study were completely unable to learn eyeblink conditioning. Thus, the present results are consistent with findings from rabbit lesions studies and suggest that the cerebellar cortex has important involvement in normal eyeblink conditioning.

When $p c d$ mutants were presented with repeated CS alone trials, they exhibited extinction of acquired CRs. This finding suggests that the Purkinje cells and thus the entire cerebellar cortex (because the Purkinje cells are the sole efferent neurons of the cortex) are not necessary for the extinction of eyeblink CRs. In rabbits, however, it was reported recently that post-training lesions of the anterior lobe of cerebellar cortex prevent extinction of eyeblink CRs (Perrett and Mauk, 1995). It is possible that the differences in species and/or procedures (e.g., airpuff US used with rabbits vs shock US used with mice) may account for this discrepancy.

The $p c d$ mice are known to exhibit cerebellar symptoms such as impaired motor coordination and mild ataxia (Goldowitz and Eisenman, 1992); however, the deficit in eyeblink conditioning in $p c d$ animals is probably not caused by deficits in sensory or motor factors. They did not differ from the wild types in terms of sensitivity to the shock (Fig. 8), UR performance to the US (Fig. 8), and startle response to a burst of white noise (personal observations). Furthermore, recent studies suggest that impairments in motor coordination can be dissociated from impairments in eyeblink conditioning (Chen et al., 1995; Shibuki et al., in press). The $p c d$ mice are also impaired in hidden platform training, but not in visible platform training, in the Morris water maze task (Goodlett et al., 1992). Thus, the learning deficit in $p c d$ mice is probably not attributable to motivational factors.

It is possible that the learning deficit observed in $p c d$ mice may 

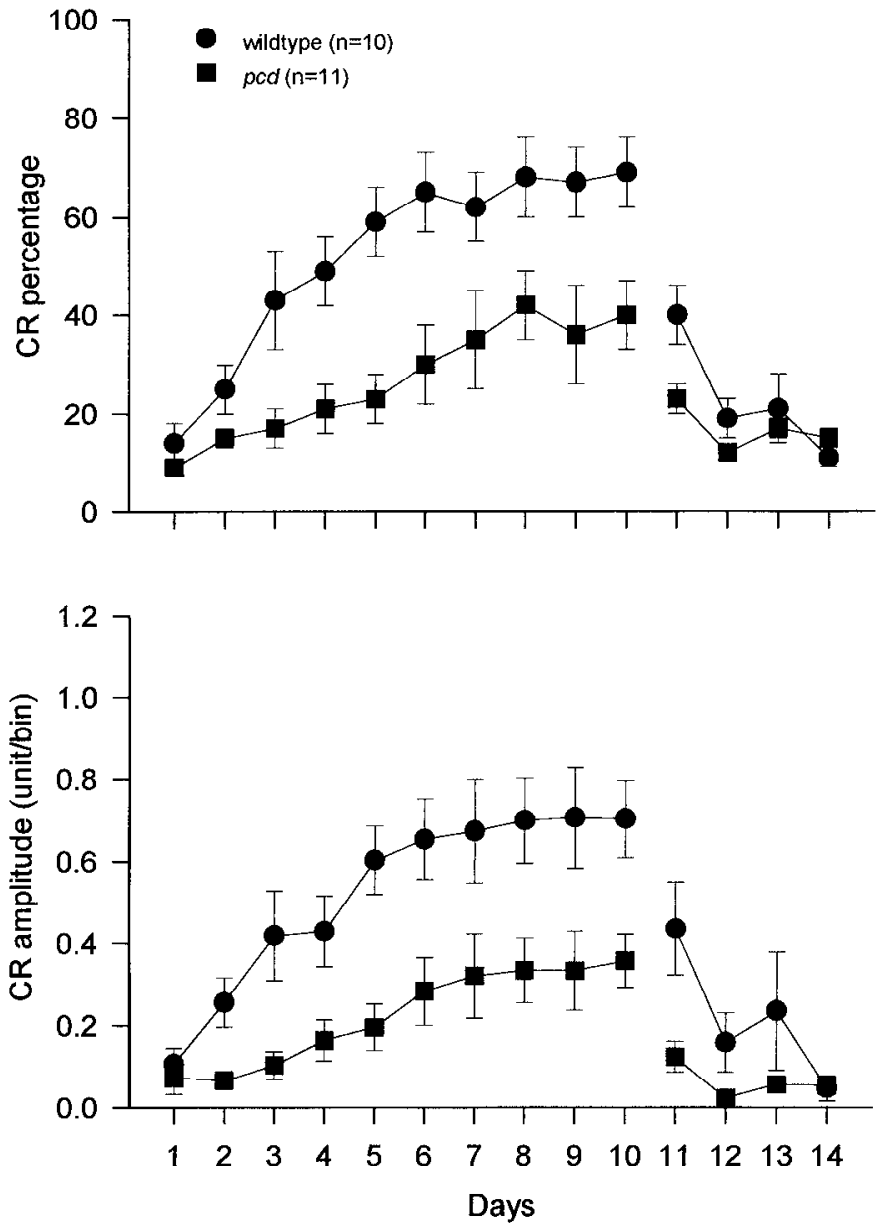

Figure 9. Percentage of CRs (top) and CR amplitudes (bottom) exhibited by $p c d(\square)$ and wild-type (O) mice during $10 \mathrm{~d}$ of acquisition and $4 \mathrm{~d}$ of extinction.

be caused in part by the degeneration of neuronal elements other than or in addition to the Purkinje cells. As mentioned earlier, the $p c d$ mice are initially born with Purkinje cells. By the third and fourth postnatal weeks of development, however, $p c d$ mutants lose their Purkinje cells (Mullen et al., 1976; Landis and Mullen, 1978; Goodlett et al., 1992). Goldowitz and Eisenman (1992) stated that "the loss of the postsynaptic partner well after the period of synaptogenesis, as occurs in the pcd and nervous mutants, leaves the presynaptic cell population relatively intact." Others have reported that the pcd mutants show neurochemical changes in the deep cerebellar nuclei (Raffler-Tarlov et al., 1979), limited loss of inferior olivary neurons (Ghetti et al., 1987; Triarhou and Ghetti, 1991), partial degeneration of cerebellar granule cells (Ghetti et al., 1978), and retinal degeneration (Mullen and La Vail, 1975). These neural degenerations observed in $p c d$ mice are considered to be secondary to Purkinje cell degeneration, and they tend to occur during a much slower time course (beginning at $\sim 3-4$ weeks of age). The $p c d$ animals used in the present study were $\sim 10$ weeks old, and our histological analyses do show other neural degenerative effects in addition to the Purkinje neurons. There was a small decline in the number of granule cells in the cerebellar cortex, but because there were no Purkinje cells (thus no output from cortex), this seems unlikely to contribute to the impairment in eyeblink conditioning. We did not notice any reduction of cells in the pontine nuclei that send projections to the

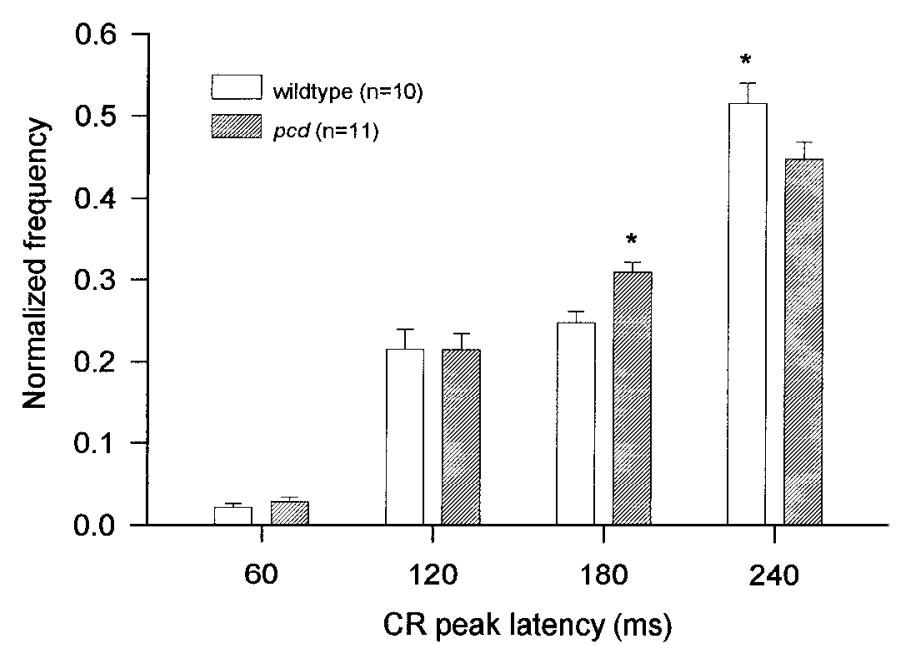

Figure 10. Normalized histogram of $\mathrm{CR}$ peak latencies from $p c d$ and wild-type mice.

granule cells and to the interpositus nucleus. The hippocampus also seemed normal in the pcd mice. The olivary cells in the $p c d$ animals, however, seemed to be smaller than those in the wild types. As noted earlier, the climbing fibers from the inferior olive relay US information to the cerebellar cortex and nuclei, and lesions to this structure prevent eyeblink conditioning in rabbits (McCormick et al., 1985; Yeo et al., 1986). According to Triarhou and Ghetti (1991), the number of inferior olive cells declines by $18 \%$ by postnatal day 23 and by $49 \%$ by postnatal day 300 . Thus, deficits in eyeblink conditioning in $p c d$ mice may be attributable, in part, to the degeneration of neurons in the inferior olive. The neurochemical changes in the interpositus nucleus (resulting from complete loss of GABAergic Purkinje cells) may also contribute to the impairment in eyeblink learning observed in pcd mutants. The possibility of retinal degeneration affecting eyeblink conditioning can be ruled out because this task does not require any visual cues. Recently, it has been shown that neonatal exposure to the antimitotic agent methylazoxymethanol, which disrupts cerebellar circuitry (e.g., misalignment of Purkinje cells) without any overt dysmorphology in other brain regions (e.g., normal appearance of the inferior olive, pontine nuclei, red nuclei, and cerebellar deep nuclei), severely impaired eyeblink conditioning in rats (Freeman et al., 1995). Thus, eyeblink conditioning can be disrupted with a confined abnormality to the cerebellar cortex, as we have demonstrated with $p c d$ mutant mice.

Similar impairments in eyeblink conditioning have also been reported in gene knockout mice that lack metabotrophic glutamate receptors (mGluR1) (Aiba et al., 1994) and glial fibrillary acidic protein (GFAP) (Shibuki et al., in press). Both mGluR1 and GFAP mutants also show deficits in cerebellar LTD. LTD is a long-lasting decrease in parallel fiber-Purkinje cell synapses after conjoint stimulation of the parallel fibers and the climbing fibers (Ito et al., 1982; Ekerot and Kano, 1985; Linden, 1994) and has been proposed as a synaptic mechanism underlying certain aspects of cerebellar-dependent learning (Ito, 1984, 1989; Thompson, 1990; Chen and Thompson, 1995). In PKC $\gamma$ mutant mice (deficient in the $\gamma$ isoform of protein kinase C), cerebellar LTD is normal and eyeblink conditioning is unimpaired (Chen et al., 1995). Thus, the absence of LTD or Purkinje cells seems to produce similar deficits in eyeblink conditioning, suggesting that synaptic processes such as LTD that occur on Purkinje neurons may play a role in normal eyeblink learning. 

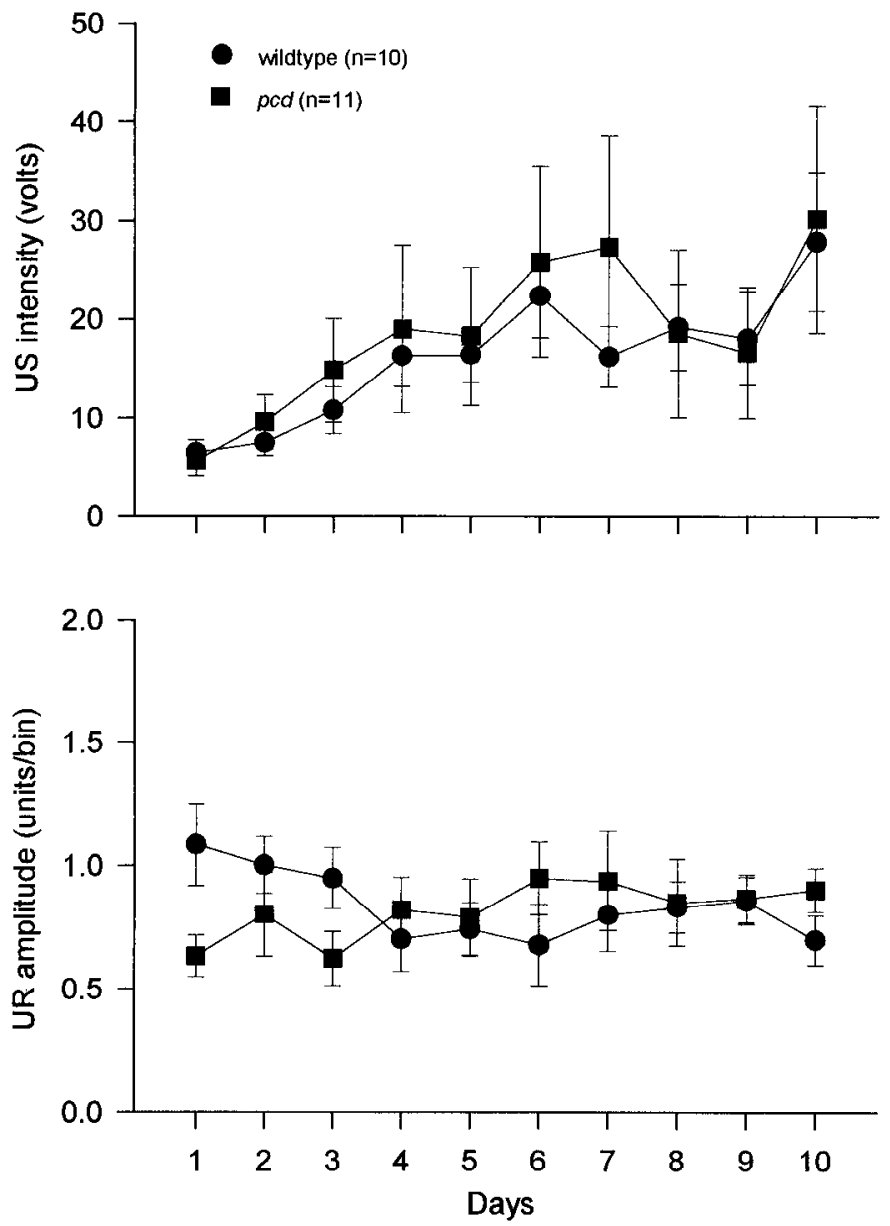

Figure 11. Sensitivity to the shock US (top) and UR (bottom) responses to the US exhibited by pcd ( $\mathbf{(})$ and wild-type $(\mathbf{O})$ mice.

In addition to eyeblink conditioning (present study) and spatial abilities (Goodlett et al., 1992), the $p c d$ mutants are impaired in other behavioral tasks, such as spontaneous alternation and exploration (Lalonde et al., 1987). Different cerebellar mutant mice such as weavers (with almost complete loss of granule cells and $\sim 28 \%$ loss of Purkinje cells), staggerers (with prominent degenerations of Purkinje cells, granule cells, and inferior olive neurons), and nervous (with selective loss of Purkinje cells and deep cerebellar nuclei) also exhibit deficits in spontaneous alternation, exploration, and habituation (Lalonde et al., 1986, 1988a,b). Eyeblink conditioning, however, has not yet been tested in these mutants.

In summary, the present study supports the notion that the cerebellum is essential for classical eyeblink conditioning in mammals. In the absence of Purkinje cells, eyeblink learning still occurs, but it is substantially attenuated and the timing of the learned response is altered. In contrast, lesions of the interpositus nucleus completely prevent eyeblink conditioning. Thus, it seems that the cerebellar cortex is important for normal eyeblink conditioning. The cerebellar cortex is also important for other forms of motor learning, such as plasticity of the vestibulo-ocular reflex (VOR) (Ito, 1984, 1989), and our results indicating that the Purkinje cells are critical for eyeblink conditioning are consistent with a recently proposed computational VOR model (du Lac et al., 1995). The availability of various cerebellar mutant, gene knockout, and transgenic mice offers a new and exciting means to explore the relationship between cerebellar circuitry, neuronal mechanisms, and behavior.

\section{REFERENCES}

Aiba A, Kano M, Chen C, Stanton ME, Gox GD, Herrup K, Zwingman TA, Tonegawa S (1994) Deficient cerebellar long-term depression and impaired motor learning in mGluR1 mutant mice. Cell 79:377-388.

Berthier NE, Moore JW (1986) Cerebellar Purkinje cell activity related to the classically conditioned nictitating membrane response. Exp Brain Res 63:341-350.

Chan-Palay V (1977) Cerebellar dentate nucleus: organization, cytology, and transmitters. Berlin: Springer.

Chen C, Thompson RF (1995) Temporal specificity of long-term depression in parallel fiber-Purkinje synapses in rat cerebellar slice. Learn and Mem 2:185-198

Chen C, Kano M, Abeliovich A, Chen L, Bao S, Kim JJ, Hashimoto K, Thompson RF, Tonegawa $S$ (1995) Impaired motor coordination correlates with persistent multiple climbing fiber innervation in $\mathrm{PKC} \gamma$ mutant mice. Cell 83:1233-1242.

Clark GA, McCormick DA, Lavond DG, Thompson RF (1984) Effects of lesions of cerebellar nuclei on conditioned behavioral and hippocampal neuronal responses. Brain Res 291:125-136.

Clark RE, Zhang AA, Lavond DG (1993) Reversible lesions of the cerebellar interpositus nucleus during acquisition and retention of a classically conditioned behavior. Behav Neurosci 106:879-888.

Courville J, Augustine JR, Martel P (1977) Projections from the inferior olive to the cerebellar nuclei in the cat demonstrated by retrograde transport of horseradish peroxidase. Brain Res 130:405-419.

Daum I, Schugens MM, Ackermann H, Lutzenberger W, Dichgans J, Birbaumer N (1993) Classical conditioning after cerebellar lesions in humans. Behav Neurosci 107:748-756.

du Lac S, Raymond JL, Sejnowski TJ, Lisberger SG (1995) Learning and memory in the vestibulo-ocular reflex. Annu Rev Neurosci 18:409-441.

Ekerot CF, Kano M (1985) Long-term depression of parallel fibre synapses following stimulation of climbing fibres. Brain Res 342:357-360.

Freeman JH, Barone S, Stanton ME (1995) Disruption of cerebellar maturation by an antimitotic agent impairs the ontogeny of eyeblink conditioning in rats. J Neurosci 15:7301-7314.

Gerfen CR, Sawchenko PE (1984) An anterograde neuroanatomical tracing method that shows detailed morphology of neurons, their axons and terminals: immunohistochemical localization of an axonally transported plant lectin, Phaseolus vulgaris leucoagglutinin (PHA-L). Brain Res 290:219-238.

Goldowitz D, Eisenman LM (1992) Genetic mutations affecting murine cerebellar structure and function. In: Genetically defined animal models of neurobehavioral dysfunctions (Driscoll P, ed), pp 66-88. Boston: Birkhauser.

Goodlett CR, Hamre KM, West IR (1992) Dissociation of spatial navigation and visual guidance performance in Purkinje cell degeneration (pcd) mutant mice. Behav Brain Res 47:129-141.

Grant SGN, Silva AJ (1994) Targeting learning. Trends Neurosci 17:71-75.

Ito $M$ (1984) The cerebellum and neural control. New York: Raven.

Ito M (1989) Long-term depression. Annu Rev Neurosci 12:85-102.

Ito M, Sakurai M, Tongroach P (1982) Climbing fibre induced depression of both mossy fiber responsiveness and glutamate sensitivity of cerebellar Purkinje cells. J Physiol (Lond) 324:113-134.

Kitai ST, McCrea RA, Preston RJ, Bishop GA (1977) Electrophysiological and horseradish peroxidase studies of precerebellar afferents to the nucleus interpositus anterior. I. Climbing fiber system. Brain Res 122:197-214.

Krupa DJ, Thompson JK, Thompson RF (1993) I ocalization of a memory trace in the mammalian brain. Science 260:989-991.

Lalonde R, Botez MI, Boivin D (1986) Spontaneous alternation and habituation in a t-maze in nervous mutant mice. Behav Neurosci 100:350-352.

Lalonde R, Manseau M, Botez MI (1987) Spontaneous alternation and habituation in Purkinje cell degenteration mulant mice. Brain Res 411:187-189.

Lalonde R, Manseau M, Botez MI (1988a) Spontaneous alternation and exploration in staggerer mutant mice. Behav Brain Res 27:273-276.

Lalonde R, Manseau M, Botez MI (1988b) Spontaneous alternation and exploration in weaver mutant mice. Behav Brain Res 31:111-114.

Landis SC, Mullen RJ (1978) The development and degeneration of Purkinje cells in pcd mutant mice. J Comp Neurol 177:125-144. 
Lavond DG, Steinmetz JE (1989) Acquisition of classical conditioning without cerebellar cortex. Behav Brain Res 33:113-164.

Lavond DG, Hembree TL, Thompson RF (1985) Effects of kainic acid lesions of the cerebellar interpositus nucleus on eyelid conditioning in the rabbit. Brain Res 326:179-182.

Lavond DG, Kim JJ, Thompson RF (1993) Mammalian brain substrates of aversive classical conditioning. Annu Rev Psychol 44:317-342.

Lavond DG, Steinmetz JE, Yokaitis MH, 'Thompson RF (1987) Reacquisition of classical conditioning after removal of cerebellar cortex. Exp Brain Res 67:569-593.

Lincoln JS, McCormick DA, Thompson RF (1982) Ipsilateral cerebellar lesions prevent learning of the classically conditioned nictitating membrane/eyelid response. Brain Res 67:569-593.

Linden DJ (1994) Long-term synaptic depression in the mammalian brain. Neuron 12:457-472.

Logan CG (1991) Cerebellar cortical involvement in excitatory and in hibitory classical conditioning. $\mathrm{PhD}$ thesis, Stanford University.

Mauk MD, Steinmetz JE, Thompson RF (1986) Classical conditioning using stimulation of the inferior olive as the unconditioned stimulus. Proc Natl Acad Sci USA 83:5349-5353.

McCormick DA, Thompson RF (1984a) Cerebellum: essential involvement in the classically conditioned eyelid response. Science 223:296-299.

McCormick DA, Thompson RF (1984b) Neuronal responses of the rabbit cerebellum during acquisition and performance of a classically conditioned nictitating membrane-eyelid response. J Neurosci 4:2811-2822.

McCormick DA, Lavond DG, Clark GA, Kettner RE, Rising CE, Thompson RF (1981) The engram found? Role of the cerehellum in classical conditioning of nictitating membrane and eyelid responses. Bull Psychonomic Soc 18:103-105.

McCormick DA, Steinmetz JE, Thompson RF (1985) Lesions of the inferior olivary complex cause extinction of the classically conditioned eyeblink response. Brain Res 359:120-130.

Mihailoff GA (1994) Identification of pontocerebellar axon collateral synaptic boutons in the rat cerebellar nuclei. Brain Res 648:313-318.

Molchan SE, Sunderland T, McIntosh AR, Herscovitch P, Schreurs BG (1994) A functional anatomical study of associative learning in humans. Proc Natl Acad Sci USA 91:8122-8126.

Mullen RJ, La Vail MM (1975) Two new types of retinal degeneration in cerebellar mutant mice. Nature 258:528-530.

Mullen RJ, Eicher EM, Sidman RL (1976) Purkinje cell degeneration, a new neurological mutation in the mouse. Proc Natl Acad Sci USA 73:208-212.

Nordholm AF, Thompson JK, Dersarkissian C, Thompson RF (1993) Lidocaine infusion in a critical region of cerebellum completely prevents learning of the conditioned eyeblink response. Behav Neurosci 107:882-886.

Perrett SP, Mauk MD (1995) Extinction of conditioned eyelid responses requires the anterior lobe of cerebellar cortex. J Neurosci 15: 2074-2080.
Perrett SP, Ruiz BP, Mauk MD (1993) Cerebellar cortex lesions disrupt learning-dependent timing of conditioned eyelid responses. J Ncurosci 13:1708-1718

Racine RJ, Wilson DA, Gingell R, Sunderland D (1986) Long-term potenliation in the interpositus and vestibular nuclei in the rat. Exp Brain Res 63:158-162.

Schreurs BG, Sanchez-Andres JV, Alkon DL (1991) Learning-specific differences in Purkinje-cell dendrites of lobule HVI (Lobulus simplex): intracellular recording in a rabbit cerebellar slice. Brain Res 548:18-22.

Shibuki K, Gomi H, Chen L, Bao S, Kim JJ, Wakatsuki H, Fujisaki T, Fujimoto K, Ikeda T, Chen C, Thompson RF, Itohara S (1996) Deficient cerebellar long-term depression, impaired eyeblink conditioning and normal motor conrdination in GFAP mutant mice. Neuron, in press.

Shinoda Y, Suguichi Y, Futami T, Izawa R (1992) Axon collaterals of mossy fibers from the pontine nucleus in the cerebellar dentate nucleus. J Neurophysiol 67:547-560.

Skelton RW (1988) Bilateral cerebellar lesions disrupt conditioned eyelid responses in unrestrained rats. Behav Neurosci 102:586-590.

Steinmetz JE, Sengelaub DR (1992) Possible conditioned stimulus pathway for classical eyelid conditioning in rabbits. I. Anatomical evidence for direct projections from the pontine nuclei to the cerebellar interpositus nucleus. Behav Neural Biol 57:103-115.

Steinmetz JE, Rosen DJ, Chapman PF, Lavond DG, Thompson RF (1986) Classical conditioning of the rabbit eyelid response with a mossy fiber stimulation CS. I. Pontine nuclei and middle cerebellar peduncle stimulation. Behav Neurosci 100:871-880.

Steinmetz. JE, Lavond DG, Thompson RF (1989) Classical conditioning in rabbits using pontine nucleus stimulation as a conditioned stimulus and inferior olive stimulation as an unconditioned stimulus. Synapse 3:225-233.

Thompson RF (1986) The neurobiology of learning and mcmory. Science 233:941-947.

Thompson RF (1990) Neural mechanisms of classical conditioning in mammals. Philos Trans R Soc Lond [Biol] 329:161-170.

Triarhou LC, Ghetti B (1991) Stabilisation of neurone number in the inferior olivary complex of aged "Purkinje cell degeneration" mutant mice. Acta Neurophathol (Berl) 81:597-602.

Voogd J (1982) The olivocerebellar projection in the cat. In: The cerebellum (Palay SL, Chan-Palay V, eds), pp 134-161. New York: Springer.

Woodruff-Pak DS, Cronholm JF, Sheffield JB (1990) Purkinje cell number related to rate of classical conditioning. NeuroReport 1:165-168.

Yeo CH, Hardiman MJ, Glickstein M (1984) Discrete lesions of the cerebellar cortex abolish the classically conditioned nictitating membrane response of the rabbit. Behav Brain Res 13:261-266.

Yeo CH, Hardiman MJ, Glickstcin M (1985) Classical conditioning of the nictitating membrane response of the rabbit. II. Lesions of the cerebellar cortex. Exp Brain Res 60:99-113.

Yeo CH, Hardiman MJ, Glickstein M (1986) Classical conditioning of the nictitating membrane response of the rabbit. IV. Lesions of the inferior olive. Exp Brain Res 63:81-92. 